expression can be derived in which the absolute value of mobility is proportional to the square root of the sample resistance change (as a fraction of the original resistance and using unit magnetic field). It is thus a simple matter to balance a resistance bridge with the sample in one arm at zero magnetic field, then apply the magnetic field and use electronic means to rebalance the bridge. The electronics can then indicate the resistance change directly or, by using a circuit which performs a squareroot operation, indicate directly the absolute value of 'magnetoresistance mobility'.

Howes has compared Hall mobilities with the magnetoresistance mobilities for

\section{Key to caddis}

LIMNOLOGISTS who have been brought up with the Scientific Publications of the Freshwater Biological Association will welcome the latest addition to the series-a key to the adults of the British Trichoptera by T. T. Macan (No. 28, $£ 1.25)$. Caddis flies are not the easiest of freshwater animals to identify and this key, illustrated with drawings of specimens which have not been allowed to shrivel, should greatly simplify study of the order. In this figure, one of many drawn for the key by C. Joan Worthington, (a) legs of Mesophylax impunctatus; (b) mid-leg of Agrypnia pagetana; (c) Glyphotaelius pellucidus, preserved specimen; $(d-h)$ heads from above and from side; (d) Phryganea varia; (e) Limnephilus rhombicus; (f) Rhyacophila dorsalis; ( $g$ ) Phryganea varia; (h) L. rhombicus.

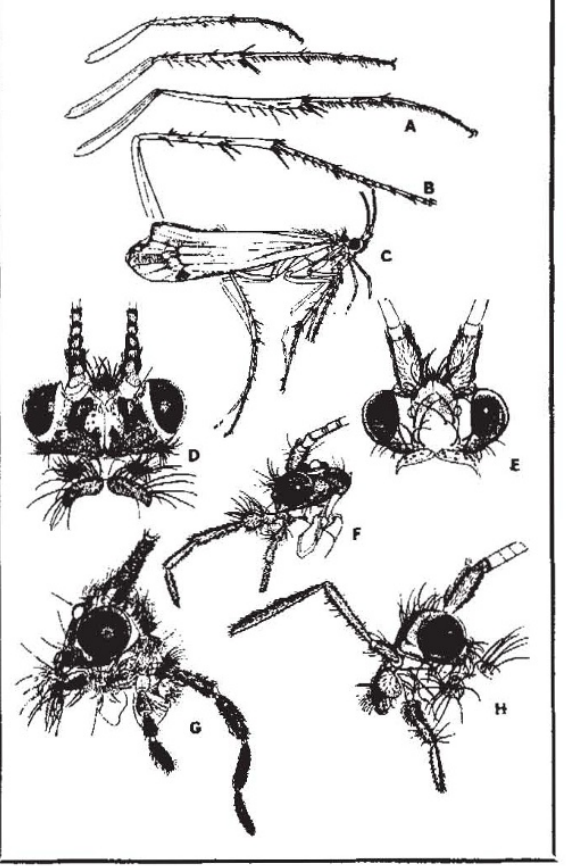

several samples of germanium, silicon, gallium arsenide and indium phosphide and found that the ratio of the two values rarely varies more than $5 \%$ from unity. Thus, the method can at worst be described as a rough-and-ready $\mathrm{Hall}$ measurement and, at best, could make some tedious forms of Hall measurement unnecessary.

\section{Integration of \\ proviruses}

from a Correspondent

$\mathrm{I}_{\mathrm{T}}$ is now 10 years since Temin postulated that RNA tumour viruses replicate by way of a DNA intermediate, the provirus. This hypothesis, for many years regarded as heresy, gained general acceptance in 1970 with the discovery of an RNA-dependent DNA polymerase (reverse transcriptase) in RNA tumour virus particles. Last year, Linial and Mason (Virology, 53, 258; 1973) reported that the reverse transcriptase does indeed play an essential part in the function of these viruses because mutants of Rous sarcoma virus, which are temperature sensitive for the enzymatic activity, cannot replicate in nor transform cells infected at the nonpermissive temperature.

It has proved more difficult, however, to demonstrate the formation of proviruses inside infected cells. Until recently, attempts to find new proviruses by molecular hybridisation have been thwarted by the presence of endogcnous viral genetic information in the natural host cells. Schincariol and Joklik (Virology, 56, 532; 1973) have now demonstrated the formation in infected cells of additional sequences of DNA homologous to the RNA of Rous sarcoma virus (RSV). Schincariol and Joklik used a sensitive single-stranded DNA probe synthesised from RSV RNA by reverse transcriptase in the presence of actinomycin D. The DNA represents more than $90 \%$ of the RNA genome. Reassociation kinetics of the complementary DNA in the presence of excess DNA prepared from infected and uninfected chick cells indicate that two copies of RSV provirus are made in addition to the one viral genome equivalent endogenous in chick cells. By hybridising excess RNA prepared from cells at different times after infection to the single-stranded DNA probe, Schincariol and Joklik also examined the initiation of transeription of the proviruses and found that 100 copies were transcribed within $24 \mathrm{~h}$ of infection.

The complicating factor of endogenous viral genetic information may be avoided by infecting unnatural host cells; for instanee, mimmalian cells do not have DNA homologous to avian tumour virus RNA. Thus Varmus,
Vogt and Bishop (J. molec. Biol., 74, $613 ; 1973)$ found two to four avian proviruses in mammalian cells transformed by RSV but none in uninfected cells. Varmus, Vogt and Bishop (Proc. natn. Acad. Sci. U.S.A., 70, 3067; 1973) now report that the viral DNA becomes covalently linked to host DNA following transformation of mouse, rat, or duck cells with RSV. Varmus et al. make use of Britten's observations that most high molecular weight DNA extracted from higher organisms contains reiterated sequences. When unsheared DNA is incubated to low $C_{n} t$ values at which repeated, but not unique, sequences reassociate, 'networks' of DNA are formed which can be separated from the remainder of the DNA by sedimentation. Much of the DNA homologous to viral RNA in transformed cells was found in the networks, thus demonstrating its integration into the host genome.

Varmus et al. then examined the formation and integration of viral DNA in freshly infected cells. Duck cells are permissive for replication of certain strains of RSV and were found to contain no endogenous sequences homologous to the RNA of RSV. Virusspecific DNA was detected within $3 \mathrm{~h}$ of infection and using the 'network' assay, integration of viral DNA was detected from $6 \mathrm{~h}$ onwards. Mouse 3T3 cells are not permissive for RSV replication and have a very low efficiency of transformation by RSV, relative to chick or duck cells. Readily detectable levels of RSV DNA, however, were found in 3T3 cells within $12 \mathrm{~h}$ of infection, though the RSV DNA did not become integrated until several hours later. These observations suggest that the RSV particles enter and form proviruses in 3T3 colls at an efficiency comparable to that in permissive cells, although transformation is less than one thousand times as efficient. It will be interesting to see whether viral RNA is transcribed off the proviruses in these 'silent' infections.

Integration of the DNA provirus provides an explanation how RNA tumour viruses, like DNA tumour viruses, can become preserved in infected cells and cause stable transformation. Does this mean that all integrating viruses could be tumour viruses? One exception is Visnil virus, which causes a 'slow' demyelinating discase in sheep. It has not been associated with any neoplastic disease althongh Takemoto has observed cell transformation in culture by Vinsa. Visna is an RNA virus that resembles RNA tumour viruses in structure and earries a reverse transeriptase. Haase and Varmus (Nature new" Biol., 245, 237 ; 1973) have investigated the renlication of Visna virus during lytic infection off sheep choroid plexus cells. 